\title{
NEW SERVICES OF ENERGY COMPANIES
}

\author{
MARCIN ZAWADA
}

Czestochowa University of Technology, POLAND

e-mail: marcin.zawada@wz.pcz.pl

RECEIVED
ACCEPTED
JEL
CLASSIFICATION

KEYWORDS

ABSTRACT
1 September 2017

15 December 2017

D18, L80, L94, M31, Q41

services, energy market, marketing, customer

Growing competition in the market causes that the energy companies increasingly are looking for new services that they can offer to their customers. The requirements of these customers are systematically increasing. They expect similar benefits as from other highly competitive and customer-focused industries. So some services offered by energy companies at first glance are not closely related to the energy market, and often involve very distant spheres of sales and supply of electricity. By analyzing the market it is possible to distinguish several groups of services (apart from electricity sales), which are present in the offer of energy companies. These include services accompanying the core businesses of these companies, such as home energy management systems, energy efficiency services, electrical equipment servicing, electric car charging stations and services that are no longer clearly linked to the energy market. Examples include warranty and insurance services, Internet and television signaling services, gardening services, technical customer support for individual customers, smart home building advice, authorization services and loans.

The purpose of this paper is to characterize existing and new services - not related to electricity sales - which are presently offered by energy companies operating on the energy market and to assess the benefits of the introduction of these services to the market.

\section{Introduction}

A wide range of energy products and services that are fully tailored to the needs of the energy consumers are the necessary conditions for a positive cooperation between the customer and the electricity seller, and they are at the same time one of the key elements in achieving a competitive advantage over other energy companies. 
The main products and services provided by energy companies include the sale of electricity using standard and non-standard products such as (Produkty..., 2017):

- sales of standard products, i.e. in tariff groups that result from the Tariffs of Operators System Distribution,

- sale of non-standard products, i.e. fully flexible, valuation of which is based on quotations of the Polish electricity exchange,

- sales of energy in the form of typical trading products such as baseload (constant energy value in each hour during delivery on weekdays, weekends and holidays) or peak load (constant energy from 8:00 to 22:00 on working days),

- energy sales in the form of a full supply with a flexible approach to the risk of imbalance,

- sales of energy in the form of graphs (variable energy value for each delivery period with the risk of customer imbalance).

Apart from selling electricity, companies operating on the energy market may also provide the following energy services:

- Commercial Operator Service (this service is aimed at those trading companies that have a transmission contract with the Transmission System Operator but do not have direct access to the balancing market and want to avoid charges for purchasing and operating their own WIRE system),

- Service of Technical and Commercial Operator (within this service company companies represent clients on the balancing market in the field of transmission of balanced commercial and technical graphics of the units of the planning, manufacturing and receiving units to the Transmission System Operator),

- Trade Balance Service (within this service, as the entity responsible for trade balancing, the company reports to the Transmission System Operator information on the implementation of the electricity sales agreements concluded by the users of the system and calculates the difference between the actual amount of electricity supplied or consumed and the amounts specified in those contracts for each settlement period).

All the aforementioned products and services are inseparable from electricity trading, however, the decrease in margins due to the price struggles of competing companies forces them to sell parallel new sales not necessarily related to the sale of electricity.

\section{Client in the structure of the energy market}

There are several groups of participants in the electricity market. The first of these are electricity generators, which include: system power plants, local CHPs, power plants and CHPs, hydroelectric plants, wind turbines, solar, biomass, biogas, etc. The second most important part of the market is the Transmission System Operator that manage the high voltage power of $220 \mathrm{kV}, 400 \mathrm{kV}$ and $750 \mathrm{kV}$. In Poland this function is done by Polish Power Grids (PSE-Operator). Low voltage power transmission is handled by Distribution Network Operators managing $110 \mathrm{kV}$ and lower voltage networks, i.e. those with whom the customer (end user) has a distribution agreement. They are currently in our country 185 , although the distribution market is divided between the four main distribution operators: Enea, Energa, PGE and Tauron. In Warsaw the distribution is carried out by RWE. The last group of participants in the electricity market are trading companies dealing in energy sales to end customers (about 17.05 million) and wholesale market activity (Zawada, 2011). 
Analyzing the consumer's behavior on the energy market, on the one hand, the specifics of this market in Poland and in the world should be taken into consideration, on the other hand, the progressive changes both in the rapid diffusion of modern communication technologies and in the increasing role of distributed energy. The current model based on large energy producers is gradually changing due to the emergence of electricity producers manufacturing energy for their own use; it is understood by consumers - prosumer, who, using new technological solutions, produce energy to meet their needs (Marie, Grybś-Kabocik, Put, 2016).

Research conducted by the National Consumer Confederation in 2016 reveals that the customer of energy industry is becoming to understand that in his relationship with the electricity seller he has to be no longer a petitioner. He has the right to expect similar, positive experiences from other industries - strongly competitive and customer focused. He has not yet decided to take action to change the seller, but is already considering it, is already beginning to know what his energy seller offers him and what he can expect from the competition. He expects the company to meet his needs to help him solve his problems, to anticipate and prevent those that have not yet occurred.

These studies show that small scale energy retailers are making active contact with an individual customer. As many as $82 \%$ of households declare that in addition to the invoice within last year the seller did not contact them. $73 \%$ of Poles are aware of the possibility of changing the electricity seller, it is no longer a barrier for them, but only $27 \%$ think it is very easy or easy. The potential for acquiring new customers is very high, $23 \%$ of households plan to change the vendor in the future to reduce costs. Most can not point to a company that would consider a change (Klient..., 2014; Pamuła, 2013).

From the energy market observation, its sellers take a very serious approach to the results of such research and strive to put more emphasis in their strategies on customer relationships by offering them not only electricity products and services, but also others not directly linked to the energy market.

\section{New services on the energy market}

Looking at the development of the energy market from the point of view of introducing new services, four groups of services (apart from electricity sales), which are today offered by power companies, can be distinguished. Two of these groups can be described as a companion service to their core businesses. These are:

- information services (home energy management systems, end user energy reports, energy efficiency services, Demand Side Response services, online energy consumption information for end users),

- energy services (overvoltage protection, facility upgrades, lighting, weather adaptation services, electrical equipment servicing, electric car charging points).

Two other groups of services are not connected so clearly with the energy market. Firstly, they are warranty and insurance services, Internet and television signaling services, gardening services, and technical support for individual customers. Energy companies also offer services such as intelligent house building consultancy, licensing, credit, or intellectual property licensing services. (Nowaczewski, 2015).

The characteristic feature of the complementary offer is that the basic scope of services provided by energy companies is to put them into packages with the sale of electricity. For example we can buy a package of electricity with:

- access to MS Office 365 (Energa),

- simultaneous purchase of light bulbs LED Philips (PGE),

- small law services (PGE), 
- access to medical specialists LUX MED (Enea),

- free bank account at Getin Bank (Enea),

- insurance (Enea - unemployment insurance and casualty insurance, PGE - accident insurance, unemployment insurance, temporary work incapacity insurance, hospitalization insurance, assistance insurance),

- help from a specialist in the event of an energy failure "Energy with electrician 24H” (Tauron),

- professional electrical repairs 24 hours a day „Energy with serviceman 24H” (Tauron).

PGE offers together with the Environmental Protection Bank a package of electricity sales for electricity generators from photovoltaic panels (BOŚ - makes it possible to participate in the „Prosuming” program, PGE provides electricity when the needs of a prosumer are greater than the energy generated by panels). PGE and Tauron also offer to the companies the sale of $100 \%$ renewable energy, which is certified with a proof-documents. It is a service addressed to companies whose image is important for the status of environmentally friendly entities. Energa carries under its brand an online store (sections: appliances, tools, sports and health, electronics and lighting, travel and leisure). Obviously, Energa's electricity recipients have some bonuses when using this store, such as free deliveries.

Enea within the service of ENERGIA + Professional advises on how to reduce electricity costs, offers technical and product support, and suggests how to improve the reliability of electrical power. PGE, on the other hand, will not only help to choose tariffs, but will also carry out a number of specialist services, such as capacitor banks, power quality measurements, thermovision measurements of the distribution system, one-day audit so called "walk-through", full audit of power with PQ measurements and load analysis, periodic inspection of the electrical installation together with the SV/n station review, energy efficiency audit in accordance with the Act, white-light certification consultations for energy efficiency (Nowaczewski, 2015).

Energy sales companies are outraged in advertising campaigns that encourage the use of only their services. Here are some examples of selected advertising slogans (Kulesa, 2015):

- And you - what will you do with the free electricity?

- Energy in your account. Make money on promotion (...).

- Fixed Price Guarantee Gas.

- Fixed Price Guarantee - Do not be surprised by the current up until the end of 2019.

- Guaranteed Lowest Price Plus.

- GUARANTEED: 5 PLN cheaper.

- MAXimum savings not only for seniors.

- Offer for prosumers.

- Energy-saving offer.

- Stable Offer with Premium Package.

- Lawyer with Energy - Get a fixed price guarantee up to half of 2017 and legal care Patron Direct.

- Ecological Product.

- The Internet is the cheapest.

- Cheap Gas and Safe Electricity.

- Cheaper after hours. 
- Energy service $24 / 7$ - free electro technical intervention and repair of the electrical system as a result of overvoltage.

- Sale of electricity (...). Up to $60 \%$ discount on electricity until the end of the year!

The above-mentioned examples of services offered by major electricity retailers in Poland and the variety of advertising campaigns point to a fierce fight for the customer not only through the price of energy but also the additional benefits of being a buyer of energy in this company. With the full range of services offered to current and potential customers, it is possible to read the official websites of the companies mentioned earlier.

\section{The benefits of introducing new products and sepvices}

The benefit propositions offered to customers in mature mass-media (banking, telecommunications, etc.) has taught them that they can demand a better offer from the service provider/product. On the other hand, the possibility of changing the electricity seller has become a tool of choice allowing the customers to fight for their rights in relation to the energy supplier. Increased customer awareness and an increasing number of market players have led to an increase in the number of customers who decide to switch to electricity. According to monitoring by the Energy Regulatory Office (URE), according to the state on the end of June 2017, the number of industrial customers (tariff groups A, B, C) who changed their energy supplier since 2007 was 183,862. On the other hand, among the household tariff in the households - tariff group $\mathrm{G}$ - the seller was changed by 511,035 recipients (Urząd..., 2017).

Increasing competition and growing customer awareness have led to the need to look at electricity from a different perspective. Competitors strive to respond to the specific needs of each segment by expanding their offerings. This is done by expanding energy products and adding more ones not related to energy itself. In this way energy products become similar to products offered in other industries and can be described in the following product layers scheme:

- electricity,

- additional products and services,

- customer experience.

The first layer is the delivery of electricity - these conditions respond to the preferences of consumers in terms of price, exposure to change, consumption in time zones, etc. The next layer is services and products that respond to the preferences of consumers in the purchase of products in a combined offer with other products and services, the use of new solutions, etc. The last layer is customer experience - it addresses the preferences of recipients in the form of settlements, payment terms, level of service, self-service tendencies, contact channels, degree of fulfillment of specific needs (Koniec..., 2015).

The development of additional products and services can fulfill three basic functions that improve the economics and efficiency of the customer acquisition process:

- it allows to build an extra margin,

- it is an element of differentiating the offer, allows the customer to create a value that is equivalent to a certain amount of money,

- it is the basis on which marketing communication can be based.

Selling products from other mass-market industries, while having the potential for improving profitability, can be a dangerous strategy in the long run. Mass industries meet the specific needs of customers: the telecommunications 
industry sells innovation to the customer, banking and financial security. The energy industry also needs to find a unique customer need that it can meet.

Energy companies should build a value proposition around energy competencies or associated with the power industry. Energy connotations with safety and stability can be used to build a wide range of products.

The energy product is much more than the supply of energy (electricity, gas, heat) - it can be a comprehensive media management service. It is important, however, to find a sufficient market for an "energy product". On mature markets, such services are built around home services. Customers living in homes are characterized by greater consumption of eclectic energy, gas and have some kind of autonomy over the management of their home installations. Therefore, an energy company can develop a wide range of products that support the maintenance of not only electricity, but also gas, and hydraulic systems, and support the customer in optimizing the energy consumption of his home, such as home warming, photovoltaic panels, etc.

\section{Conclusions}

The process of liberalization of the electricity market, among others by unbundling or by introducing the TPA principle significantly accelerated the development of the services provided on this market. We can observe that apart from the core services resulting from the Transmission System Operator and Distribution Network Operators concession services, there are also services provided by trading companies and commercial operators.

The widespread trend among energy companies is the widening of the offered product - offering energy companies a wide range of products and services, both energy-efficient and completely outside the sector's interest (so-called service packages). According to this strategy, power companies are transforming not only into multienergy companies that provide different energy sources, but also in multi-media companies providing very diverse packages of products and services. In the case of energy companies, the potential product may be both a substitute product (e.g. introduction to the offer of electricity companies) and a product complementary to the primary product - the energy carrier (e.g. the sale of energy equipment) (Zawada, 2013).

Power companies make a profound change to their approach to customers. Traditionally, when they had monopoly status, they identified customers only from the counter or meter side at the end of the power line or pipeline. Nowadays it is necessary to know the individual needs, preferences and expectations of clients and collect as much information as possible about them. This information can be initially transformed into customer knowledge that can be used, inter alia, to predict their behavior and to more accurately determine target segments. This involves the use of increasingly sophisticated customer relationship management (CRM) systems and the use of data mining techniques (Wiernek, 2008).

One thing is certain - the market for new services offered by energy companies due to increased competition and increased consumer awareness, which will be increasingly sought in the near future, will develop dynamically.

\section{References}

Klient indywidualny na rynku energii elektrycznej (2014, November). Retrieved from: http://www.4prm.com/files/ient_indywidualny_na_ rynku_energii_elektrycznej_Raport_og__Inodost__pny.pdf (10.07.2017).

Koniec tradycyjnej energetyki? - Jak wygrać w dobie zmian (2015). Raport PWC i ING Banku Śląskiego. Retrieved from: https://www. pwc.pl/pl/publikacje/assets/pwc-ing-raport-koniec-tradycyjnej-energetyki.pdf (25.07.2017). 
Kulesa, M. (2015). Nowe produkty na rynku energii elektrycznej jako rozszerzenie oferty Operatorów Telekomunikacyjnych - wybrane zagadnienie. Retrieved from: http://www.wasko.pl/wp-content/uploads/2015/05/Rozszerznie_oferty_o_produkty_z_rynku_ energii_elektrycznej1.pdf (15.07.2017).

Marie, A., Grybś-Kabocik, M., Put, A. (2016). Wirtualizacja zachowań konsumentów na rynku usług energetycznych. Retrieved from: https://www.cars.wz.uw.edu.pl/tresc/konferencje/25/Wirtualizacja_zachowan_konsumentow.pdf (1.07.2017).

Nowaczewski, G. (2015, September). Komu są potrzebne nowe usługi przedsiębiorstw energetycznych. Retrieved from: http:/l grzegorznowaczewski.innpoland.pl/121061,komu-sa-potrzebne-nowe-uslugi-przedsiebiorstw-energetycznych (15.07.2017).

Pamuła, A. (2013). Aspekty komunikacji klient indywidualny-dostawca energii elektrycznej w aktualnych i przyszłych sieciach elektroenergetycznych. Zeszyty Naukowe Uniwersytetu Szczecińskiego, 763. Ekonomiczne Problemy Usług, 105, 363-372.

Produkty i usługi (2017). Retrieved from: http://www.cezpolska.pl/pl/produkty/energia-elektryczna/produkty-i-uslugi.html (10.07.2017).

Urząd Regulacji Energetyki. Retrieved from: www.ure.gov.pl.

Wiernek, M. (2008). Marketing produktu w polskich przedsiębiorstwach gazowniczych na europejskim rynku energii. Retrieved from: http://winntbg.bg.agh.edu.pl/rozprawy2/10076/full10076.pdf (30.07.2017).

Zawada, M. (2011). Przesył i dystrybucja energii elektrycznej w Polsce. Logistyka, 5.

Zawada, M. (2013). Marketing activities on the energy market in the European Union. Visnik Nacional'nogo Universitetu 'L'vivs'ka Politehnika", 762. Logistika, 66-73.

Cite this article aS: Zawada, M. (2018). New services of energy companies. European Journal of Service Management, 2 (26), 345-351. DOI: 10.18276/ejsm.2018.26-43. 